\title{
Effect on Merlot red wine of fining agents mixture: application of the simplex centroid design
}

\author{
Evandro FICAGNA ${ }^{1 *}$ (D), Angelo GAVA ${ }^{1}$, Simone Bertazzo ROSSATO ${ }^{1}$, \\ César Valmor ROMBALDI², Dionísio BORSATO ${ }^{3}$
}

\begin{abstract}
In the elaboration of young red wine, it is necessary to obtain a clear product with stable color. The clarity and stability can be obtained using fining agents. The objective of this study was to evaluate the combined effect of fining with pea protein isolate (PPI), bentonite, and polyvinylpyrrolidone (PVPP) on a red wine, using the experimental design of mixtures. Merlot wine was used to evaluate the changes on monomeric flavan-3-ol, turbidity and anthocyanin levels promoted by the fining compounds. For all the parameters, the adjusted models showed influence of the combination of the three fining agents. Together, bentonite and PVPP have synergistic effect on the reduction in monomeric flavanol levels. Such synergistic effect was also observed with PPI and PVPP combination for the reduction in turbidity. However, for this same characteristic (turbidity), the combination of PPI and bentonite has antagonistic effect. To achieve broader wine fining objectives, the simultaneous optimization of the three response variables demonstrated the importance of the presence of the three refining agents in the following proportions: 25\% PPI, $43 \%$ PVPP and 32\% Bentonite. The isolated use of these additives would not result in the same effect on the three studied variables.
\end{abstract}

Keywords: pea protein isolate; PVPP; bentonite; anthocyanins; monomeric flavan-3-ols; turbidity.

Practical Application: This study may demonstrate the of use of combination of fining agents is crucial for red wine quality.

\section{Introduction}

In the production of red wine intended to be consumed young, it is important to obtain a clear and colored stable product. Such red wine is marketed in a shorter time than is necessary to obtain a spontaneous stabilization. Deciding on enological practices, such as the choice of grape variety, harvest time, maceration and fermentation types, and the lack or addition of winemaking inputs is technically challenging. Moreover, several new cultural, ideological, or purely commercial concepts are introduced in enology (Cargnello, 2009).

The fining of wines is a widely employed enological practice, even though a wide range of variations exists in the process (Tschiersch et al., 2010). The primary goal of fining is to promote the clarification of wine and to improve its stability. In red wines, fining agents are added to remove the phenolic substances, thereby avoiding colloidal precipitation and making the wine more clear and stable (Yokotsuka \& Singleton, 1995; Marchal et al., 2002).

Commercially, various substances are available as fining agents, for example: gelatin, casein, egg albumin, activated charcoal, bentonite, polyvinylpolypyrrolidone (PVPP), and more recently, vegetables proteins (Boulton et al., 2013; Ribéreau-Gayon et al., 2006; Gibson, 2013; Jiménez-Martínez et al., 2019; Vernhet, 2019). The choice depends on the proposed objectives, the nature of the wine, and the compounds to be removed during the process.
The bentonite is the commercial name of a natural clay mineral, whose main component is montmorillonite. Its use is universally accepted for the adsorption of proteins in wines (Blade \& Boulton, 1988). Proteins with isoelectric point values above the $\mathrm{pH}$ of wine have a positive charge in wine and readily interact with bentonite (Blade \& Boulton, 1988; Úbeda, 2000). Bentonite may indirectly bind phenols that have complexed with proteins and can also bind anthocyanins, with a consequent loss of color (Donovan et al., 1998; Dordoni et al., 2015). Bentonite is efficient in reducing turbidity caused by proteins and colloidal dyestuff material, promoting stability of red wines (Ribéreau-Gayon et al., 2006).

The polyvinylpolypyrrolidone (PVPP) is a high molecular weight vinylpyrrolidone polymer (about 1.000 .000 ) and is water insoluble. It is a synthetic fining agent that tends to form bonds with phenolic compounds of lower molecular weight (Sims et al., 1995; Donovan et al., 1998), promoting the reduction in the levels of total polyphenols, phenolic acids, procyanidins, catechins, polyphenols, and protein complexes. Mechanism of adsorption of polyphenols on PVPP is similar to the mechanism of flocculation of gelatin and tannin, with formation of hydrogen bonds between the phenolic groups and oxygen of the amine group of the pyrrolidone ring (Togores, 2018).

Currently, the pea protein isolate, an adequate alternative to proteins of animal origin or proteins with an allergenic potential 
(Tschiersch et al., 2010; Smith et al., 2015; Vernhet, 2019), has been commercialized by oenological input companies both in pure form and in combination with other agents. Most of the widespread commercial protein fining agents for wine are of animal origin. However with the discovery of the transmissible nature of Bovine Spongiform Encephalopathy (BSE) and due to the concerns about the potential risk of allergies and food intolerance from products of animal origin, the search for a new protein source was initiated (Marchal et al., 2002; Maury et al., 2003; Jiménez-Martínez et al., 2017). In recent works, it is observed that vegetable proteins are as effective as proteins of animal origin in the fining of red wines (Ben Aziz et al., 2017; Granato et al., 2018; Ficagna et al., 2019).

Within the main companies that supply enological inputs, it is normal to offer ready mixtures of fining agents for use in wines. Despite several studies comparing fining agents, to date there have been no published studies evaluating the effect of the combination of three agents on the physico-chemical characteristics of red wine. One hypothesis for this practice would be that bentonite is used to flocculate proteins as it forms a colloidal dispersion of negative electrical charge in wine that can modify the positive electrical charge of proteins, producing bond and flocculation between two colloids (Togores, 2018). In this case, resulting in the clarification of the wine without the removal of part of the tannins, these were responsible for bitterness and would be free to be removed by the PVPP.

The objective of this study was to investigate the combined fining effect of pea protein isolate (PPI), bentonite, and PVPP on the reduction of monomeric flavanols, turbidity, and anthocyanin content of a young red wine, using experimental mixture design.

\section{Materials and methods}

\subsection{Wine}

For the experiment, Merlot red wine (Vitis vinifera) was vinified with grapes from the 2012 vintage, in the Serra Gaucha region (Brazil). The winemaking process for cultivar started with a homogenous volume of $200 \mathrm{~L}$ of must, prepared following destemming, crushing, enzyme treatment (commercial pectinase $20 \mathrm{mg} \mathrm{L}^{-1}$ ), addition of sulphite (50 mg L $\mathrm{m}^{-1}$ ), yeast (250 $\mathrm{mg} \mathrm{L}^{-1}$ ) and supplementation with nutrient Thiazote (Laffort, Bordeaux, France) a combined of ammonium salts and hydrochloride thiamine (250 $\left.\mathrm{mg} \mathrm{L}^{-1}\right)$, maceration (seven days), racking, spontaneous malolactic fermentation, and additional sulphite (adjusted with $30 \mathrm{mg} \mathrm{L}^{-1}$ free $\mathrm{SO}_{2}$ ) supplementation.
Merlot variety was used because of its adaptation to the climate and soil of the Serra Gaúcha; it also represents a significant portion of the grapes processed in the region (Machado et al., 2017) and provides a wine intended to be consumed young (Rizzon \& Miele, 2003).

The physicochemical characteristics of the wines used in the experiment are shown in Table 1 . The alcoholic content $\left(\mathrm{mL} \mathrm{L}^{-1}\right)$ of wines was determined using an enochemical distilling unit (Gibertini, Milan, Italy). Determination of density, total and volatile acidity, and total and free $\mathrm{SO}_{2}$ were performed according to OIV methods (Organisation Internationale de la Vigne et du Vin, 2009). The determination of sugar content $\left(\mathrm{g} \mathrm{L}^{-1}\right)$ was performed based on the methodology of Lane-Eynon (Brasil, 2005). The $\mathrm{pH}$ was determined with an MPA210 benchtop pH meter (Tecnopon, Brazil) according to OIV methods (Organisation Internationale de la Vigne et du Vin, 2009). The analyses were performed one month after the malolactic fermentation.

\subsection{Fining agents}

For the formulation of the mixtures the following substances were tested: polyvinylpolypyrrolidone (PVPP), commercial name: Divergan F, provided by BASF SA (Ludwigshafen, Germany); bentonite, commercial name: E-Benthon Extra (Perdomini, Verona, Italy), and pea protein isolate [Pisum sativum] (PPI), commercial name: FITOPROTEINA P, provided by Vason (Verona, Itália).

\subsection{Fining experiments}

Application of the fining agents was performed after malolactic fermentation, while adding $50 \mathrm{mg} \mathrm{L}^{-1}$ total sulfur dioxide (30 mg L-1 final free $\mathrm{SO}_{2}$ ) into a volume of $4.6 \mathrm{~L}$ of wine. The solution containing fining agent $(10 \% \mathrm{w} / \mathrm{v}$ in distilled water) was introduced using a centrifugal pump with a capacity of $280 \mathrm{~L} \mathrm{~h}^{-1}$, to promote its homogeneous incorporation into the wine. The same procedure was performed for the control wine, which received no fining agent but received the same volume of water equal to that used for the dilution of all the agents. After the incorporation of the agent, $4.6 \mathrm{~L}$ of the wine was packaged in glass containers and maintained at $17^{\circ} \mathrm{C}$ for seven days. The stabilized wine was separated from the precipitate by siphoning and was poured in $0.75 \mathrm{~L}$ bottles for analysis.

Table 1. Physico-chemical characteristics of Merlot wine 2012 vintage before fining.

\begin{tabular}{|c|c|c|c|}
\hline \multicolumn{4}{|c|}{ Analytical parameters $^{\mathrm{a}}$} \\
\hline Density $\left(\mathrm{g} \mathrm{L}^{-1}\right)$ & 994 & Total $\mathrm{SO}_{2}\left(\mathrm{mg} \mathrm{L}^{-1}\right)$ & 115.20 \\
\hline Alcohol content $\left(\mathrm{mL} \mathrm{L}^{-1}\right)$ & 118.0 & Free $\mathrm{SO}_{2}\left(\mathrm{mg} \mathrm{L}^{-1}\right)$ & 31.44 \\
\hline Sugar content $\left(\mathrm{g} \mathrm{L}^{-1}\right)$ & 1.6 & Monomeric Flavanols $\left(\mathrm{mg} \mathrm{L}^{-1}\right)$ & 12.19 \\
\hline Volatile acidity ( $\mathrm{g} \mathrm{L}^{-1}$ acetic acid) & 0.48 & Turbidity (NTU) & 29.0 \\
\hline Total acidity ( $\mathrm{g} \mathrm{L}^{-1}$ tartaric acid) & 4.88 & Total Anthocyanins $\left(\mathrm{mg} \mathrm{L}^{-1}\right)$ & 519.6 \\
\hline $\mathrm{pH}$ & 3.39 & Total flavan-3-ols (mg L-1) & 374.20 \\
\hline
\end{tabular}

${ }^{\mathrm{a}}$ Means values obtained from three replicates; ${ }^{\mathrm{b}} \mathrm{NTU}=$ Nephelometric Turbidity Units. 


\subsection{Physicochemical analysis}

The anthocyanin content was determined by an adaptation of the bisulfite method, according to the procedure previously described by Chris Somers \& Evans (1977). The optical density and absorption spectra were measured with a spectrophotometer model T92+ (PG Instruments, Lutterworth, United Kingdom). Monomeric flavan-3-ol content was determined by preparatory C18 Sep-Pak separation into three major fractions, following the method proposed by Sun et al. (1998). Fractionation of neutral phenolic compounds was carried out using a C18 Sep-Pak cartridge (Waters Associates, Philadelphia, USA) according to Oszmianski et al. (1988), Mayén et al. (1995), and Gil-Muñoz et al. (1999). The neutral polyphenols retained in the cartridge were eluted using 16\% acetonitrile at pH 2.0 to collect monomeric flavan-3-ol. The turbidity of the wine was directly measured in a nephelometric turbidimeter (model AP2000, Brand PoliControl, Diadema, Brazil) that was previously calibrated with standard solutions of formazine. Turbidity was expressed in NTU (Nephelometric Turbidity Units). All analyses were performed two months after bottling.

\subsection{Experimental design and statistical analysis}

The development of a formulation involving more than two components requires some experimental specificities (Cornell, 2011). Thus, experimental mixture design (simplex centroid) was used to evaluate the behavior of mixture formed by an organic fining agent (PPI) in combination with two inorganic fining agents (PVPP and bentonite). The design for three components comprised seven tests with four replicates at the central point and two replicates at the other points (vertices and lateral). As control treatment, an additional trial was performed in duplicate where the wine underwent all the similar processes, except receiving a fining agent mixture. The upper limit for each of the fining agents was established based on previous tests, and the doses of $0.20 \mathrm{~g} \mathrm{~L}^{-1}$ and $0.5 \mathrm{~g} \mathrm{~L}^{-1}$ were used for PPI and inorganic clarifiers, respectively. The proportions in each formulation, expressed in real concentrations and in pseudocomponents (Bruns et al., 2006), are shown in Table 2.
Statistica 9.0 (StatSoft Inc., 2009) was used for planning the mixtures, analysis of the experimental data, and component optimization. The mixtures were prepared to obtain the response surfaces, using the expression of the special cubic model (Cornell, 2011) as shown in Equation 1. The mathematical models adjusted for each response were submitted to analysis of variance (ANOVA) to evaluate the significance $(\mathrm{p}<0.05)$ and the adjusted coefficient of determination (adjusted $\mathrm{R}^{2}$ ).

$\mathrm{y}=\sum_{\mathrm{i}=1}^{\mathrm{q}} \beta_{\mathrm{i}} \mathrm{x}_{\mathrm{i}}+\sum \sum_{\mathrm{i}<\mathrm{j}}^{\mathrm{q}} \beta_{\mathrm{ij}} \mathrm{x}_{\mathrm{i}} \mathrm{x}_{\mathrm{j}}+\sum \sum_{\mathrm{i}<\mathrm{j}<\mathrm{k}} \sum \beta_{\mathrm{ijk}} \mathrm{x}_{\mathrm{i}} \mathrm{x}_{\mathrm{j}} \mathrm{x}_{\mathrm{k}}$

\section{Results and discussion}

We evaluated the individual and combined effect of the three fining agents PPI, PVPP, and Bentonite, on the reduction of monomeric flavanols, turbidity, and percentage of anthocyanins in wine. According to the analysis of variance, the adjusted models explained $98 \%, 95 \%$, and $94 \%$ of the variation, respectively (Table 3). These parameters were positively influenced by the three fining agents, except for turbidity reduction where the interaction between PPI and Bentonite had a negative influence. For the three variables studied, the coefficients $\beta_{123}$ were positive with a high value compared to the other coefficients, indicating synergism. Thus, the three fining agents applied together produced a greater effect than when used individually.

\subsection{Monomeric flavan-3-ol}

The most important requirement of a protein fining agent is the reduction in bitterness and astringency in wine. The effect of fining proteins in reducing these characteristics is attributed to the interaction of the proteins with phenolic compounds, especially tannins, which are the main components responsible for astringency (Luck et al., 1994; Soares et al., 2017). Low molecular weight phenolic compounds, such as monomeric and oligomeric flavan-3-ols, might influence the bitterness of wines (Arnold et al., 1980; Thorngate \& Noble, 1995; Kallithraka et al., 1997; Hufnagel \& Hofmann, 2008; Sáenz-Navajas et al., 2010).

The reduction in the monomeric flavanols (Figure 1a) in the wine is affected with the increase in the concentration of PPI

Table 2. Matrix of the simplex-centroid experimental design with pseudocomponents, real concentrations and replicates for the mixture of three fining agents.

\begin{tabular}{|c|c|c|c|c|c|c|c|c|}
\hline \multirow{3}{*}{ Point } & \multirow{3}{*}{ Run } & \multicolumn{3}{|c|}{ Pseudocomponents } & \multicolumn{3}{|c|}{ Real concentrations $\left(\mathrm{g} \mathrm{L}^{-1}\right)$} & \multirow{3}{*}{ Replicas } \\
\hline & & $\mathrm{X}_{1}$ & $\mathrm{X}_{2}$ & $\mathrm{X}_{3}$ & $\mathrm{X}_{1}$ & $\mathrm{X}_{2}$ & $\mathrm{X}_{3}$ & \\
\hline & & PPI & PVPP & Bentonite & PPI & PVPP & Bentonite & \\
\hline Vertice 1 & 1 & 1.0 & 0.0 & 0.0 & 0.200 & 0.000 & 0.000 & 2 \\
\hline Vertice 2 & 2 & 0.0 & 1.0 & 0.0 & 0.000 & 0.500 & 0.000 & 2 \\
\hline Vertice 3 & 3 & 0.0 & 0.0 & 1.0 & 0.000 & 0.000 & 0.500 & 2 \\
\hline Lateral 1 & 4 & 0.5 & 0.5 & 0.0 & 0.100 & 0.250 & 0.000 & 2 \\
\hline Lateral 2 & 5 & 0.5 & 0.0 & 0.5 & 0.100 & 0.000 & 0.250 & 2 \\
\hline Lateral 3 & 6 & 0.0 & 0.5 & 0.5 & 0.000 & 0.250 & 0.250 & 2 \\
\hline Center & 7 & 0.33 & 0.33 & 0.33 & 0.067 & 0.167 & 0.167 & 4 \\
\hline Control & 8 & 0.0 & 0.0 & 0.0 & 0.0 & 0.0 & 0.0 & 2 \\
\hline
\end{tabular}

$\mathrm{X}_{1}=$ Pea Protein Isolate; $\mathrm{X}_{2}=$ Polyvinylpolypyrrolidone; $\mathrm{X}_{3}=$ Bentonite. $\mathrm{X}_{1}+\mathrm{X}_{2}+\mathrm{X}_{3}=1$ or $100 \%$ PPI = Pea Protein Isolate; PVPP = Polyvinylpolypyrrolidone. 
Table 3. Regression coefficients and analysis of variance of the models adjusted to the reduction of monomeric flavanols, to turbidity reduction and anthocyanin content after fining with a mixture containing PPI, PVPP and Bentonite.

\begin{tabular}{|c|c|c|c|}
\hline & Reduction of monomeric flavanols (\%) & Reduction of turbidity (\%) & Anthocyanin content (\%) \\
\hline$\beta_{1}\left(X_{1}\right)$ & $39.5113^{*}$ & $67.5500 *$ & 80.6100 * \\
\hline$\beta_{2}\left(X_{2}\right)$ & 56.7688 * & 48.3000 * & 82.1260 * \\
\hline$\beta_{3}\left(\mathbf{X}_{3}\right)$ & $14.1206^{*}$ & 87.7500 * & 77.8620 * \\
\hline$\beta_{12}$ & -5.0666 & $71.9000 *$ & -3.4960 \\
\hline$\beta_{13}$ & -8.7173 & $-38.8000 *$ & 6.0780 \\
\hline$\beta_{23}$ & 30.6057 * & 6.9000 & -5.7000 \\
\hline$\beta_{123}$ & 214.5591 * & 219.7500 * & 204.5955 * \\
\hline Significance of the model (p) & $<0.001$ & $<0.001$ & $<0.001$ \\
\hline $\mathbf{R}^{2}$ adjusted & 0.98 & 0.95 & 0.94 \\
\hline
\end{tabular}

$\mathrm{X}_{1}=$ Pea Protein Isolate; $\mathrm{X}_{2}=$ PVPP; $\mathrm{X}_{3}=$ Bentonite; PPI = Pea Protein Isolate; PVPP = Polyvinylpolypyrrolidone; ${ }^{\star}$ Significant coefficients $(\mathrm{p}<0.05)$.

(a)

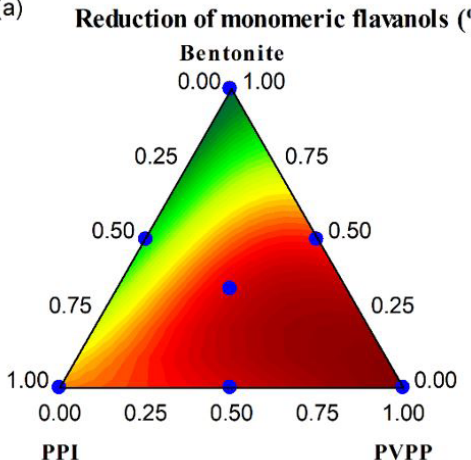

\%)

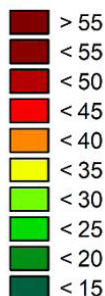

(c)
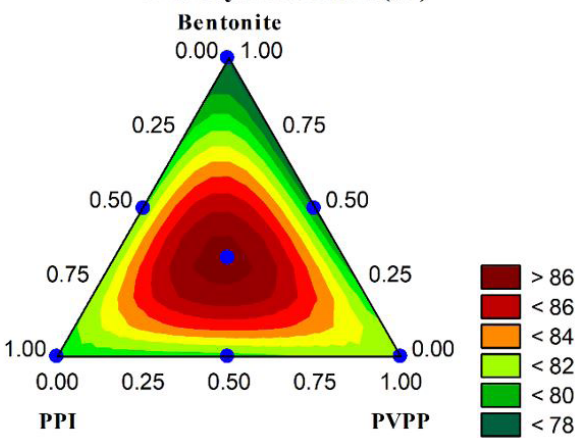

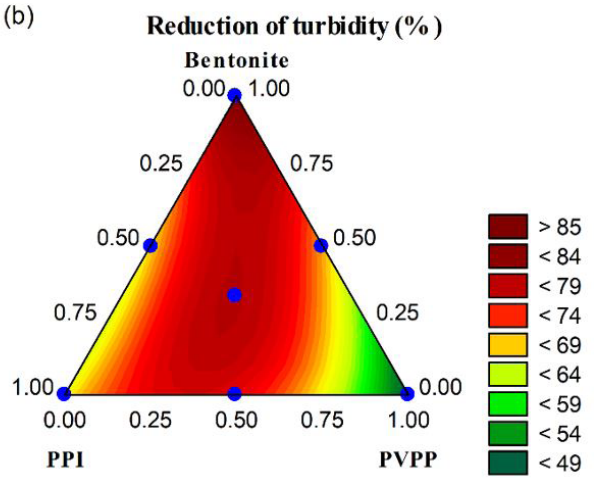

Figure 1. Triangular diagrams with the level curves obtained by the experimental model (in terms of pseudocomponents) for the reduction of monomeric flavanols (a), turbidity reduction (b) and anthocyanin content (c) in red wine after fining. Area between points delimits a region analyzed experimentally. PPI = Pea Protein Isolate; PVPP = Polyvinylpolypyrrolidone.

and Bentonite in the mixture. Similar to the results obtained by Ben Aziz et al. (2017), we observed that combining PVPP and Bentonite resulted in a greater reduction in flavan-3-ol levels compared to that achieved by treatment with the combination of pea protein isolate and bentonite.

Bentonite alone showed the lowest reduction in these phenolic compounds $(<15 \%)$, whereas PVPP alone exhibited the greatest effect $(>55 \%)$. This result was expected since PVPP is a synthetic fining agent compound that tends to form bonds with monomeric and small polyphenols owing to a conformational preference that allows hydrogen bonding of the carboxylic groups (PVPP) with the phenolic hydrogens (Donovan et al., 1998). Puškaš \& Miljić (2012), while studying the effects of different fining agents on red wine removal of $(+)$-catechins and (-) -epicatechins, observed less removal of bentonite (19-25\%) versus PVPP (30-35\%).

\subsection{Turbidity}

The fining aims to eliminate wine turbidity, the visible particles that absorb or deflect light (Blouin \& Peynaud, 2004). The reduction in was lower when PPI and PVPP were used alone, while bentonite 
reduced $(>85 \%)$ turbidity in wines drastically. These results are in agreement with those of Gazzola et al. (2017), in which clarification with PVPP and pea protein in Chardonnay wine resulted in a marginal reduction in turbidity $( \pm 6 \%)$. Pea protein did not reduce turbidity of Raboso Red wine. González-Neves et al. (2014) studying the reduction in turbidity of young wines also noted that bentonite promoted greater reduction than other fining agents such as vegetable proteins, albumin, and gelatin.

In this study, the interaction between the three fining agents at the central point, and between PPI and PVPP promoted a greater reduction of turbidity, showing synergism (Figure $1 \mathrm{~b}$ ). The interaction between PPI and bentonite, as mentioned previously, had a negative effect, indicating that these two components have an antagonistic effect. Our results differ from those of Iturmendi et al. (2010), who observed that combining proteins of vegetal origin with bentonite did not lead to any significant effect on the turbidity reduction, when compared to the use of vegetal proteins individually.

The isoelectric point of the PPI is greater than the $\mathrm{pH}$ of the wine, and when diluted it becomes positively charged. The adsorption of proteins in wine by bentonites is due primarily to the cation exchange action of these clays (Blade \& Boulton, 1988), based on electrostatics, hydrophobicity, and/or hydrophilic interactions (Staunton \& Quiquampoix, 1994; Gougeon et al., 2002). The observed antagonism may be explained by the interaction between PPI and bentonite, partially canceling out their effects.

\subsection{Total anthocyanins}

The anthocyanin content of post-fining wines was higher at the central point (Figure 1c). The coefficients related to the binary mixtures did not present statistical significance, only the term of the cubic coefficient (mixture of the three clarifiers) showed significance. According to the coefficients of these variables, the effect of the three agents individually is very similar, and the equilibrium of the mixture of the three components promotes a higher content of anthocyanins at the end of the fining.

The decrease in the total anthocyanin levels using fining agents tested is recognized by several authors (Triberti, 1992; Castillo-Sánchez et al., 2006, 2008; González-Neves et al., 2014). Recent studies have indicated a high retention of anthocyanins while using Bentonite, whereas the effect of the pea protein isolate was not significant for three red wines (Jiménez-Martínez et al., 2019). In previous work, Dordoni et al. (2015) found a reduction in anthocyanin content in Valpolicella wines treated with three of four bentonites studied. In a comparative study among fining agents in red wine, bentonite showed a greater reduction in the total anthocyanin content in comparison to the control wine, and the mixture of PVPP and casein resulted in a reduction similar to that achieved with bentonite. Furthermore, use of vegetable protein resulted in the smallest reduction in anthocyanin content (Ghanem et al., 2017).

\subsection{Mixture optimization}

To better evaluate the importance of the combination of the three fining agents, the ratio between the agents was optimized so that the blend maximized the to the three responses variables. Thus, combination of $25 \%$ PPI, $43 \%$ PVPP, and $32 \%$ bentonite produced the best results (Figure 2). These data revealed that, to improve one set of characteristics at the end of the fining, the blend of the three fining agents gives superior results than the use of isolated agent or the combination of two of these

\section{Profiles for Expected Values and Desirability}

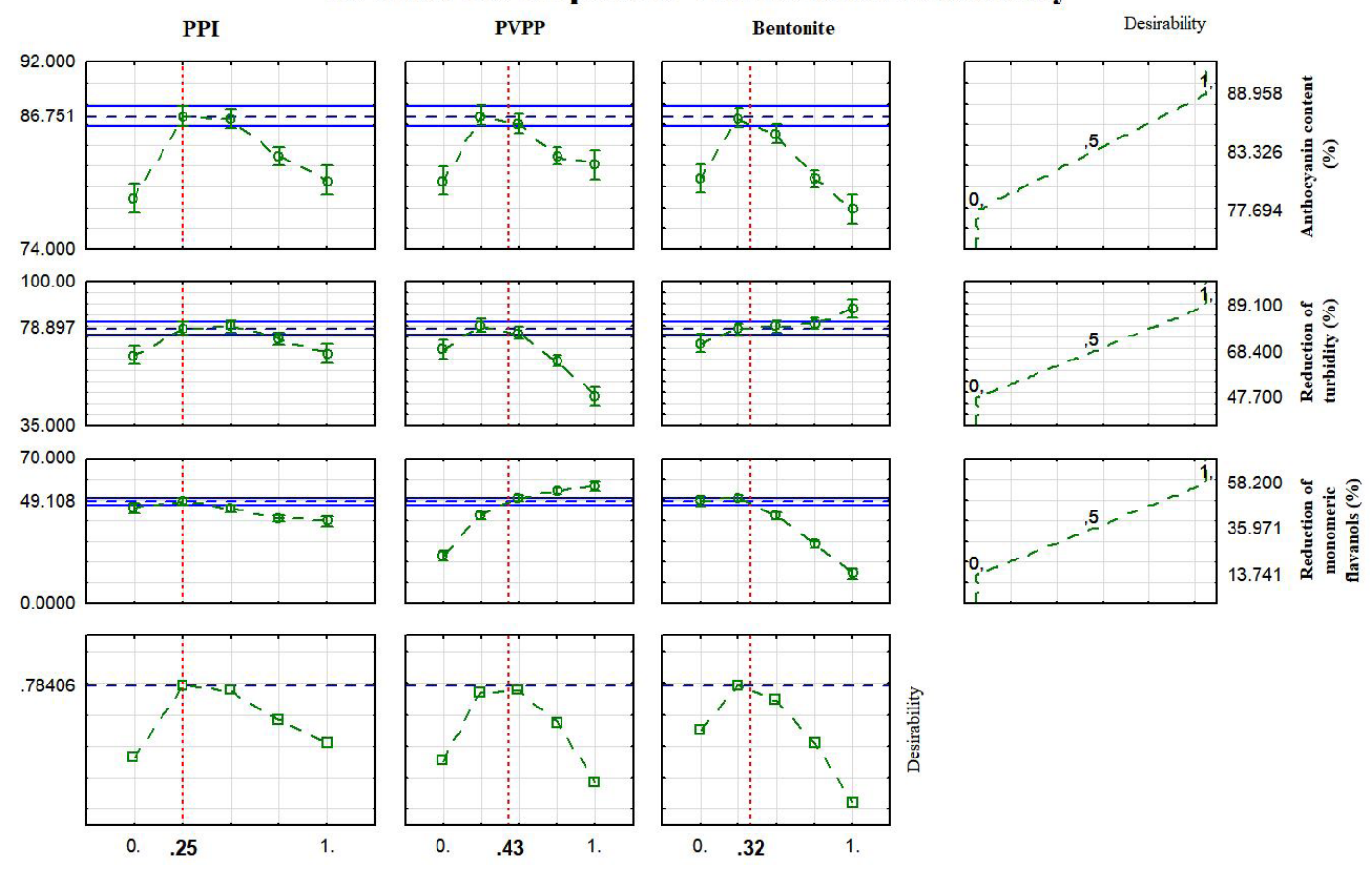

Figure 2. Graphs obtained through the methodology of Derringer \& Suich (1980). Optimization of fining agents mixing conditions to maximize studied variables. PPI = Pea Protein Isolate; PVPP = Polyvinylpolypyrrolidone. 
agents. The synergistic effect can be explained by the hypothesis previously mentioned. In addition, each fining agent acts on a determined portion of compounds present in the medium, making the simultaneous presence of these responsible for the improvement of the different parameters.

\section{Conclusions}

Bentonite and PVPP combination showed a synergistic effect for the reduction in monomeric flavanol levels. Mixture of PPI and PVPP showed a synergistic effect in the reduction of turbidity. However, the combination of PPI and bentonite has an antagonistic effect in turbidity, where the agents were partially annulled. The combination of the three agents resulted in a higher content of anthocyanins in wine. Through the simultaneous optimization of the three response variables studied, it was demonstrated that the presence of the three fining agents is important during the process. According to predictive modeling, the proportion of $25 \%$ PPI, $43 \%$ PVPP, and $32 \%$ bentonite get in superior results to isolated use of these additives.

\section{Acknowledgements}

The authors would like to thank IFRS (Instituto Federal de Educação, Ciência e Tecnologia do Rio Grande do Sul), CAPES (Coordenação de Aperfeiçoamento de Pessoal de Nível Superior), CNPq (Conselho Nacional de Desenvolvimento Científico e Tecnológico) and FAPERGS (Fundação de Amparo à Pesquisa do Estado do Rio Grande do Sul).

\section{References}

Arnold, R. A., Noble, A. C., \& Singleton, V. L. (1980). Bitterness and astringency of phenolic fractions in wine. Journal of Agricultural and Food Chemistry, 28(3), 675-678. http://dx.doi.org/10.1021/ jf60229a026.

Ben Aziz, M., Mouls, L., Fulcrand, H., Douieb, H., \& Hajjaj, H. (2017). Phenolic compounds of Moroccan red press wines: Influence of fining agents and micro-oxygenation treatments. LebensmittelWissenschaft + Technologie, 78, 143-150. http://dx.doi.org/10.1016/j. lwt.2016.12.034.

Blade, W. H., \& Boulton, R. (1988). Adsorption of protein by bentonite in a model wine solution. American Journal of Enology and Viticulture, 39(3), 193-199.

Blouin, J., \& Peynaud, E. (2004). Enología práctica: conocimiento y elaboración del vino. Madrid: Mundi-Prensa Libros.

Boulton, R. B., Singleton, V. L., Bisson, L. F., \& Kunkee, R. E. (2013). Principles and practices of winemaking. New York: Springer Science \& Business Media.

Brasil, Ministério da Agricultura. (2005). Dispõe sobre manual operacional de bebidas e vinagres (Instrução normativa $n^{\circ} 24$, de 8 de setembro de 2005). Diário Oficial [da] República Federativa do Brasil.

Bruns, R. E., Scarminio, I. S., \& Barros, B. No. (2006). Statistical designchemometrics (Vol. 25). Amsterdam: Elsevier.

Cargnello, G. (2009). Great chain: urgent necessity the focusing on the metaethical viticulture or great viticulture: research and various considerations. In Proceedings of the 16th International Symposium GiESCO (pp. 31-35). Davis: University of California.

Castillo-Sánchez, J. J., Mejuto, J. C., Garrido, J., \& García-Falcón, S. (2006). Influence of wine-making protocol and fining agents on the evolution of the anthocyanin content, colour and general organoleptic quality of Vinhão wines. Food Chemistry, 97(1), 130-136. http:// dx.doi.org/10.1016/j.foodchem.2005.03.030.

Castillo-Sánchez, J. X., García-Falcón, M. S., Garrido, J., MartínezCarballo, E., Martins-Dias, L. R., \& Mejuto, X. C. (2008). Phenolic compounds and colour stability of Vinhão wines: influence of winemaking protocol and fining agents. Food Chemistry, 106(1), 18-26. http://dx.doi.org/10.1016/j.foodchem.2007.04.069.

Chris Somers, T., \& Evans, M. E. (1977). Spectral evaluation of young red wines: anthocyanin equilibria, total phenolics, free and molecular $\mathrm{SO}_{2}$,"chemical age". Journal of the Science of Food and Agriculture, 28(3), 279-287. http://dx.doi.org/10.1002/jsfa.2740280311.

Cornell, J. A. (2011). Experiments with mixtures: designs, models, and the analysis of mixture data (Vol. 403). New York: John Wiley \& Sons. http://dx.doi.org/10.1002/9780470907443.

Derringer, G., \& Suich, R. (1980). Simultaneous optimization of several response variables. Journal of Quality Technology, 12(4), 214-219. http://dx.doi.org/10.1080/00224065.1980.11980968.

Donovan, J. L., McCauley, J. C., Nieto, N. T., \& Waterhouse, A. L. (1998). Effects of small-scale fining on the phenolic composition and antioxidant activity of merlot wine. In A. L. Waterhouse \& S. E. Ebeler (Eds.), ACS symposium series. Washington: American Chemical Society. http://dx.doi.org/10.1021/bk-1998-0714.ch011.

Dordoni, R., Galasi, R., Colangelo, D., De Faveri, D. M., \& Lambri, M. (2015). Effects of fining with different bentonite labels and doses on colloidal stability and colour of a Valpolicella red wine. International Journal of Food Science \& Technology, 50(10), 2246-2254. http:// dx.doi.org/10.1111/ijfs.12875.

Ficagna, E., Gava, A., Rossato, S. B., Rombaldi, C. V., \& Zavareze, E. R. (2019). Application of soy protein isolate in the fining of red wine. Ciência e Técnica Vitivinícola, 34(1), 48-60. http://dx.doi. org/10.1051/ctv/20193401048.

Gazzola, D., Vincenzi, S., Marangon, M., Pasini, G., \& Curioni, A. (2017). Grape seed extract: the first protein-based fining agent endogenous to grapes. Australian Journal of Grape and Wine Research, 23(2), 215-225. http://dx.doi.org/10.1111/ajgw.12268.

Ghanem, C., Taillandier, P., Rizk, M., Rizk, Z., Nehme, N., Souchard, J. P., \& El Rayess, Y. (2017). Analysis of the impact of fining agents types, oenological tannins and mannoproteins and their concentrations on the phenolic composition of red wine. Lebensmittel-Wissenschaft + Technologie, 83, 101-109. http://dx.doi.org/10.1016/j.lwt.2017.05.009.

Gibson, R. (2013). Fining and stabilisation. Adelaide: Trivinum Press.

Gil-Muñoz, R., Gómez-Plaza, E., Martınez, A., \& López-Roca, J. M. (1999). Evolution of phenolic compounds during wine fermentation and post-fermentation: influence of grape temperature. Journal of Food Composition and Analysis, 12(4), 259-272. http://dx.doi. org/10.1006/jfca.1999.0834.

González-Neves, G., Favre, G., \& Gil, G. (2014). Effect of fining on the colour and pigment composition of young red wines. Food Chemistry, 157, 385-392. http://dx.doi.org/10.1016/j.foodchem.2014.02.062. PMid:24679795.

Gougeon, R. D., Reinholdt, M., Delmotte, L., Miehé-Brendlé, J., Chézeau, J. M., Le Dred, R., Marchal, R., \& Jeandet, P. (2002). Direct observation of polylysine side-chain interaction with smectites interlayer surfaces through ${ }^{1} \mathrm{H}-{ }^{27} \mathrm{Al}$ heteronuclear correlation NMR spectroscopy. Langmuir, 18(8), 3396-3398. http://dx.doi.org/10.1021/la0115381.

Granato, T. M., Ferranti, P., Iametti, S., \& Bonomi, F. (2018). Affinity and selectivity of plant proteins for red wine components relevant to color and aroma traits. Food Chemistry, 256, 235-243. http://dx.doi. org/10.1016/j.foodchem.2018.02.085. PMid:29606443. 
Hufnagel, J. C., \& Hofmann, T. (2008). Orosensory-directed identification of astringent mouthfeel and bitter-tasting compounds in red wine. Journal of Agricultural and Food Chemistry, 56(4), 1376-1386. http:// dx.doi.org/10.1021/jf073031n. PMid:18193832.

Iturmendi, N., Durán, D., \& Marín-Arroyo, M. R. (2010). Fining of red wines with gluten or yeast extract protein. International Journal of Food Science \& Technology, 45(2), 200-207. http://dx.doi. org/10.1111/j.1365-2621.2009.02121.x.

Jiménez-Martínez, M. D., Bautista-Ortín, A. B., Gil-Muñoz, R., \& Gómez-Plaza, E. (2019). Comparison of fining red wines with purified grape pomace versus commercial fining agents: effect on wine chromatic characteristics and phenolic content. International Journal of Food Science \& Technology, 54(4), 1018-1026. http:// dx.doi.org/10.1111/ijfs.13881.

Jiménez-Martínez, M. D., Gómez-Plaza, E., Molero, N., \& Bautista-Ortín, A. B. (2017). Fining of red wines with pomace cell wall material: effect on wine phenolic composition. Food and Bioprocess Technology, 10(8), 1531-1539. http://dx.doi.org/10.1007/s11947-017-1922-3.

Kallithraka, S., Bakker, J., \& Clifford, M. N. (1997). Evaluation of bitterness and astringency of (+)-catechin and (-)-epicatechin in red wine and in model solution. Journal of Sensory Studies, 12(1), 25-37. http://dx.doi.org/10.1111/j.1745-459X.1997.tb00051.x.

Luck, G., Liao, H., Murray, N. J., Grimmer, H. R., Warminski, E. E., Williamson, M. P., Lilley, T. H., \& Haslam, E. (1994). Polyphenols, astringency and proline-rich proteins. Phytochemistry, 37(2), 357-371. http://dx.doi.org/10.1016/0031-9422(94)85061-5. PMid:7765619.

Machado, C. A. E., de Mello, L. M. R., Guzzo, L. C., Zanesco, R., Fialho, F. B., \& Hoff, R. (2017). Georreferenciamento do cadastro vitícola do Rio Grande do Sul: situação em 2015. In L. M. R. Mello \& C. A. E. Machado (Eds.), Cadastro Vitícola do Rio Grande do Sul: 2013 a 2015 (cap. 2, pp. 31-51). Brasília: Embrapa Uva e Vinho.

Marchal, R., Marchal-Delahaut, L., Lallement, A., \& Jeandet, P. (2002). Wheat gluten used as a clarifying agent of red wines. Journal of Agricultural and Food Chemistry, 50(1), 177-184. http://dx.doi. org/10.1021/jf0105539. PMid:11754564.

Maury, C., Sarni-Manchado, P., Lefebvre, S., Cheynier, V., \& Moutounet, M. (2003). Influence of fining with plant proteins on proanthocyanidin composition of red wines. American Journal of Enology and Viticulture, 54(2), 105-111.

Mayén, M., Mérida, J., \& Medina, M. (1995). Flavonoid and non-flavonoid compounds during fermentation and post-fermentation standing of musts from Cabernet Sauvignon and Tempranillo grapes. American Journal of Enology and Viticulture, 46(2), 255-261.

Organisation Internationale de la Vigne et du Vin - OIV. (2009). Compendium of international methods of wine and must analysis. Paris: OIV.

Oszmianski, J., Ramos, T., \& Bourzeix, M. (1988). Fractionation of phenolic compounds in red wine. American Journal of Enology and Viticulture, 39(3), 259-262.

Puškaš, V. S., \& Miljić, U. D. (2012). Effects of fining on phenolic compounds and colour of red wine obtained with addition of increased amounts of grape solid phase in pomace. Hemijska Industrija, 66(5), 727-734. http://dx.doi.org/10.2298/HEMIND111209018P.

Ribéreau-Gayon, P., Glories, Y., Maujean, A., \& Dubourdieu, D. (2006). Handbook of enology: the chemistry of wine-stabilization and treatments (Vol. 2). Chichester: John Wiley \& Sons.
Rizzon, L. A., \& Miele, A. (2003). Avaliação da cv. Merlot para elaboração de vinho tinto. Food Science and Technology, 23, 156-161. http:// dx.doi.org/10.1590/S0101-20612003000400029.

Sáenz-Navajas, M. P., Ferreira, V., Dizy, M., \& Fernández-Zurbano, P. (2010). Characterization of taste-active fractions in red wine combining HPLC fractionation, sensory analysis and ultraperformance liquid chromatography coupled with mass spectrometry detection. Analytica Chimica Acta, 673(2), 151-159. http://dx.doi.org/10.1016/j. aca.2010.05.038. PMid:20599029.

Sims, C. A., Eastridge, J. S., \& Bates, R. P. (1995). Changes in phenols, color, and sensory characteristics of muscadine wines by pre-and post-fermentation additions of PVPP, casein, and gelatin. American Journal of Enology and Viticulture, 46(2), 155-158.

Smith, P. A., McRae, J. M., \& Bindon, K. A. (2015). Impact of winemaking practices on the concentration and composition of tannins in red wine. Australian Journal of Grape and Wine Research, 21, 601-614. http://dx.doi.org/10.1111/ajgw.12188.

Soares, S., Brandão, E., Mateus, N., \& de Freitas, V. (2017). Sensorial properties of red wine polyphenols: Astringency and bitterness. Critical Reviews in Food Science and Nutrition, 57(5), 937-948. http://dx.doi.org/10.1080/10408398.2014.946468. PMid:25897713.

StatSoft Inc. (2009). Graphics software, v. 9.0. Tulsa: Statistica For Windows.

Staunton, S., \& Quiquampoix, H. (1994). Adsorption and conformation of bovine serum albumin on montmorillonite: modification of the balance between hydrophobic and electrostatic interactions by protein methylation and $\mathrm{pH}$ variation. Journal of Colloid and Interface Science, 166(1), 89-94. http://dx.doi.org/10.1006/jcis.1994.1274.

Sun, B., Leandro, C., Ricardo da Silva, J. M., \& Spranger, I. (1998). Separation of grape and wine proanthocyanidins according to their degree of polymerization. Journal of Agricultural and Food Chemistry, 46(4), 1390-1396. http://dx.doi.org/10.1021/jf970753d.

Thorngate, J. H. 3rd, \& Noble, A. C. (1995). Sensory evaluation of bitterness and astringency of 3R (-)-epicatechin and $3 \mathrm{~S}(+)$-catechin. Journal of the Science of Food and Agriculture, 67(4), 531-535. http:// dx.doi.org/10.1002/jsfa.2740670416.

Togores, J. H. (2018). Tratado de enología (Vol. 2). Madrid: MundiPrensa Libros.

Triberti, M. G. (1992). Effetti del trattamento con bentonite sulla composizione e sulle proprietà dei vini rossi. Annali dell'Istituto Sperimentale per l'Enologia Asti, 23(1), 319-342.

Tschiersch, C., Nikfardjam, M. P., Schmidt, O., \& Schwack, W. (2010). Degree of hydrolysis of some vegetable proteins used as fining agents and its influence on polyphenol removal from red wine. European Food Research and Technology, 231(1), 65-74. http://dx.doi. org/10.1007/s00217-010-1253-3.

Úbeda, R. M. (2000). Teoría de la clarificación de mostos y vinos y sus aplicaciones prácticas. Madrid: Mundi Prensa.

Vernhet, A. (2019). Red wine clarification and stabilization. In A. Morata (Ed.), Red wine technology (chap. 16, pp. 237-251). London: Academic Press. http://dx.doi.org/10.1016/B978-0-12-814399-5.00016-5.

Yokotsuka, K., \& Singleton, V. L. (1995). Interactive precipitation between phenolic fractions and peptides in wine-like model solutions: turbidity, particle size, and residual content as influenced by $\mathrm{pH}$, temperature and peptide concentration. American Journal of Enology and Viticulture, 46(3), 329-338. 